\title{
Atorvastatin: In-Vivo Synergy with Metronidazole as Anti-Blastocystis Therapy
}

\author{
Maha M. A. Basyoni', Shawky A. Fouad², Marwa F. Amer ${ }^{3}$, Ahmed Fathy Amer', Dalia Ibrahim Ismail ${ }^{5}$ \\ 'Medical Parasitology Department, Faculty of Medicine, Cairo University, Egypt; IInternal Medicine Department, Faculty of Medicine, Cairo University, \\ Egypt; ${ }^{3}$ Medical Biochemistry and Molecular Biology Department, Faculty of Medicine, Cairo University, Egypt; ${ }^{4}$ Child Health Department, National \\ Research Center, Cairo, Egypt; ${ }^{5}$ Histology Department, Faculty of Medicine, Cairo University, Egypt
}

\begin{abstract}
Blastocystis is an enteric Straminopile in tropical, subtropical and developing countries. Metronidazole has been a chemotheraputic for blastocystosis. Failures in its regimens were reported and necessitate new studies searching for alternative therapeutic agents. Aim of current study is to investigate potential effects of Atorvastatin (AVA) compared to the conventional chemotherapeutic MTZ in experimentally Blastocystis-infected mice. Anti-Blastocystis efficacy of AVA was evaluated parasitologically, histopathologically and by transmission electron microscopy using MTZ (10 mg/kg) as a control. Therapeutic efficacy of AVA was apparently dose-dependent. Regimens of AVA (20 and $40 \mathrm{mg} / \mathrm{kg}$ ) proved effective against Blastocystis infections with high reduction in Blastocystis shedding (93.4-97.9\%) compared to MTZ (79.3\%). The highest reductions (98.1\% and 99.4\%) were recorded in groups of combination treatments AVA $20-40$ mg/kg and MTZ $10 \mathrm{mg} / \mathrm{kg}$. Blastocystis was nearly eradicated by the 20th day post infection. Genotype analysis revealed that genotype I was most susceptible, genotype III was less. Histopathologic and ultrastructural studies revealed apoptotic changes in Blastocystis and significant improvement of intestinal histopathological changes more remarkable in combinational therapy groups. Thus, the present study offers AVA as a potential candidate for Blastocystis therapy combined with MTZ.
\end{abstract}

Key words: Blastocystis, atorvastatin, metronidazole, efficacy, mouse

\section{INTRODUCTION}

Blastocystis is an enteric Straminopile with low host specificity supporting its zoonotic prospect [1]. This parasite had up to $60 \%$ incidence in tropical, subtropical and developing countries. Clinical symptoms such as chronic diarrhea, dermal lesions and irritable bowel syndrome was described in patients with Blastocystis infection [2]. Stark et al. [3] suggested some inflammatory changes in chronic Blastocystis infections. Other studies proved that $B$. hominis induced enteritis and terminal ileitis in infected cases $[4,5]$. Conventional chemotherapeutics have been used in blastocystosis [6]. Currently, metronidazole is one of the drugs prescribed to human Blastocystis infections $[7,8]$. However, some failures in its chemotherapeutic regimens were reported [7]. It was suggested it was mutagenic and

- Received 28 November 2017, revised 4 April 2018, accepted 8 April 2018.

*Corresponding author (mmabulmagd@kasralainy.edu.eg; drmahaabu@gmail.com) (c) 2018, Korean Society for Parasitology and Tropical Medicine This is an Open Access article distributed under the terms of the Creative Commons Attribution Non-Commercial License (http://creativecommons.org/licenses/by-nc/4.0) which permits unrestricted non-commercial use, distribution, and reproduction in any medium, provided the original work is properly cited. carcinogenic in children $[9,10]$. This necessitates further studies searching for alternative therapeutic agents that could either replace or complement metronidazole in treatment of Blastocystis infections. Statins are inhibitors of cholesterol biosynthesis by inhibiting 3-hydroxy-3-methyl-glutaryl-coenzyme A (HMG-CoA reductase), which is a rate-limiting enzyme of the mevalonate pathway. Thus, they are frequently used as lipid-lowering agents [11]. By inhibition of cholesterol biosynthesis, statins obstruct intracellular trafficking by preventing development of isoprenoid (IPP) intermediates [12]. Furthermore, studies suggested that statins protect endothelial barrier integrity through inhibition of Rho kinase (ROCK), HMG-CoA reductase and cysteine protease $[13,14]$. Reports of rodents' models suggested Blastocystis affection of intestinal epithelial barrier integrity $[15,16]$. Also, Blastocystis induced reorganization of host epithelium tight junction complex through ROCK-mediated myosin light chain (MLC) phosphorylation leading to increased epithelial permeability [14]. During our search through literatures, there were no available reports that Blastocystis is capable of IPP synthesis suggesting that the parasites are completely dependent on host synthesis of these in- 
termediates. Moreover, pretreatment of epithelium by simvastatin prevented Blastocystis-induced epithelial barrier compromise [14].

This dual achievement of statins on epithelial barrier as well as parasite integrity suggests a new promising effect of statins on Blastocystis infections. Consequently, the aim of the current study is to investigate the potential effects of statins (AVA) compared to the conventional chemotheraputic (MTZ) in experimentally infected mice to elucidate whether these findings interpret into an effective treatment option of Blastocystis-resistant intestinal infections.

\section{MATERIALS AND METHODS}

This is a cross-sectional study which was conducted in the period from January 2016 to July 2017 in the Parasitology, Biochemistry and Molecular Biology, and Histology Departments, Faculty of Medicine, Cairo University, Egypt.

\section{Fecal samples}

Patients complaining of acute or chronic intermittent diarrhea, with or without abdominal pain were obtained from wards and outpatient clinics of the Internal Medicine Department, Cairo University hospitals. All stool samples were collected in clean sterile containers and immediately exposed to direct wet mount, iodine-stained and Giemsa-stained parasitological examination for the presence of Blastocystis or other parasitic infections. From each patient, 3 consecutive stool samples were examined and all patients with other parasitic infections were excluded from the study.

\section{Culture of Blastocystis}

Blastocystis isolates obtained from 100 stool samples were employed for culture using Jones' medium [17]. To which was added 10\% horse serum (Invitrogen, Groningen, Netherlands), $100 \mathrm{UI} / \mathrm{ml}$ penicillin and $100 \mu \mathrm{g} / \mathrm{ml}$ streptomycin (Sigma-Aldrich, St. Louis, Missouri, USA) at $37^{\circ} \mathrm{C}$ for 2-3 days. We examined the cultures for Blastocystis every $24 \mathrm{hr}$ using conventional light microscopy and sub-cultures were made for an additional 2-3 days in fresh media. Culture was negative if the organism was absent until the 7th day post-infection (PI). Daily examination of culture for trophozoites/cysts was performed to count number of Blastocystis using hemocytometer and to adjust inoculation dose to $4 \times 10^{7} / \mathrm{ml}$ culture medium [18].

\section{Experimental animals}

One hundred and twenty Swiss white mice, nearly of the same age (3-4 weeks old) and about 20-25 g each, were laboratory bred under clean conditions to be free of Blastocystis infection which is confirmed by PCR analysis of stool samples according to Parker et al. [19]. They were obtained from experimental house, Faculty of Veterinary Medicine, Cairo University. Before inoculation, viability was assessed using Eosin-brilliant cresyl blue stain (EC) [20], which stained viable cells green and non-viable cells red. Mice were inoculated orally using a $100 \mu$ micropipette (Ultipette, Barky Instruments, Folkestone, Kent, UK) with a capillary tip. Stool elutes from mice were examined for Blastocystis at different time points, i.e., 5th, 10th, 15th, and 20th day post-infection (PI). Infection intensity in stool samples was estimated according to Shlim et al. [21]. Different forms of Blastocystis were counted in at least ten fields with estimation of the average $\mathrm{N} /$ high power field (HPF). Molecular study [22] including DNA extraction and genotyping of Blasatocystis in mice stool was carried out at 20th day PI.

\section{DNA extraction}

DNA was extracted from human fecal samples, culture material, mice fecal samples and intestinal mucosal scrapings using QIAamp DNA Stool/Tissue Mini Kit (Qiagen, Hilden, Germany), as previously described [19].

\section{Genotyping by PCR using STS primers}

Consistent subtype-specific STS primers were utilized for genotyping of Blastocystis [22]. Genotype I was confirmed by 2 primers GAAGGACTCTCTGACGATGA and GTCCAAATGAAAGGCAGC detecting 351 bp. Genotype II was confirmed by utilizing ATCAGCCTACAATCTCCTC and ATCGCCACTTCTCCAAT primers to detect $650 \mathrm{bp}$. Genotype III was detected by a forward primer AGGATTTGGTGTTTGGAGA and a reverse primer TTAGAAGTGAAGGAGATGGAAG with a product of $526 \mathrm{bp}$. The fourth genotype was distinguished by GCATCCAGACTACTATCAACATT forward primer besides CCATTTTCAGACAACCACTTA reverse primer (338 bp).

The reaction was performed in a whole volume of $50 \mu \mathrm{l}$ consisting of $20 \mu$ l of template DNA; $10 \mathrm{mM}$ Tris- $\mathrm{HCl}$ (pH 9.0); $50 \mathrm{mMKCl} ; 0.1$ Triton X-100; $2 \mathrm{mM} \mathrm{MgCl} 2 ; 200 \mu \mathrm{M}$ of dCTP, dNTP, dTTP, and dGTP, $0.2 \mu \mathrm{M}$ of each primer and 1.25 $\mu \mathrm{l}$ of Taq DNA. The cycling conditions included a preliminary start of the Hot Star Taq DNA polymerase at $95^{\circ} \mathrm{C}$ for $15 \mathrm{~min}$, 
a cycle of denaturating at $94^{\circ} \mathrm{C}$ for $3 \mathrm{~min}, 30$ cycles of annealing at $59^{\circ} \mathrm{C}$ for $3 \mathrm{sec}$, extending at $72^{\circ} \mathrm{C}$ for $60 \mathrm{sec}$, denaturating at $94^{\circ} \mathrm{C}$ for $30 \mathrm{sec}$, and an additional cycle of chain elongation at $72^{\circ} \mathrm{C}$ for $5 \mathrm{~min}$. The PCR products were visualized using $1.5 \%$ agarose gel after staining with ethidium bromide.

\section{Drug formulations and doses}

Experimental animals received 2 treatments; the first one is the standard drug, MTZ (Amriya Pharm. Industry, Alexandria, Egypt) in tablet form. Stock solution of MTZ was prepared by dissolving $600 \mathrm{mg}$ in $10 \mathrm{ml}$ distilled water to give a final stock solution of $60 \mathrm{mg} / \mathrm{ml}$ and stored in the dark at $4^{\circ} \mathrm{C}$ [23]. It was given orally in a dose of $10 \mathrm{mg} / \mathrm{kg} /$ day as the dose frequently used for relevant mouse reports [24]. The second drug is AVA (AUG Pharma, Giza, Egypt) 20 mg tablets .It was given orally in 2 doses of $20 \mathrm{mg} / \mathrm{kg} /$ day and $40 \mathrm{mg} / \mathrm{kg} /$ day [25]. All medications were administered daily orally using a feeding tube ( $200 \mu \mathrm{l}$ per animal) for 5 consecutive days, beginning $24 \mathrm{hr}$ after infection with Blastocystis.

\section{Histopathology}

On the 21st day, mice were killed by cervical dislocation. Tissue samples from walls of small intestines and colons were fixed in $10 \%$ formalin, embedded in paraffin, sectioned, stained with hematoxylin-eosin (H-E), and examined under the light microscope. Only segments that were confirmed by PCR were processed for histological analysis. Slides were examined for the presence of Blastocystis, evidence of mucosal damage, inflammation or increased numbers of infiltrating leucocytes in the mucosa or any other associated pathology. The histologically visible inflammatory changes were scored blindly for each mouse and classified in to mild, moderate and severe degrees [26].

\section{Transmission electron microscopic study (TEM)}

Intestinal tissues were washed 3 times using PBS (pH 7.4) and centrifuged at $500 \mathrm{~g}$ for $5 \mathrm{~min}$. Then, re-suspended overnight in $4 \%$ glutaraldehyde in $0.1 \mathrm{M}$ sodium cacodylate buffer $(\mathrm{pH} 7.3)$ at $4^{\circ} \mathrm{C}$, washed thoroughly with cacodylate buffer and post-fixed for $30 \mathrm{~min}$ in $1 \%$ osmium tetroxide in cacodylate buffer. The fixed cells were dehydrated in ascending series of ethanol and embedded in epoxy resin. Semithin sections were stained with toluidine blue. Ultrathin sections were cut using an ultra- microtome, contrasted with uranyl acetate and lead citrate and viewed using a TEM (JEOL JEM.1400).

\section{Study design}

The infected mice were randomly divided into the following groups:

Group 1: 10 infected non-treated mice, maintained as infection control group.

Group 2: 10 mice infected and treated with MTZ (10 mg/kg) as standard drug.

Group 3: 20 mice infected and treated with AVA. They were subdivided into group $3 \mathrm{~A}$ (10 mice) given a dose of $20 \mathrm{mg} / \mathrm{kg} /$ day and group 3B (10 mice) given a dose of $40 \mathrm{mg} / \mathrm{kg} /$ day.

Group 4: 20 mice infected and treated with combinational therapy of AVA and MTZ. They were subdivided into group 4A (10 mice), given AVA at a dose of 20 $\mathrm{mg} / \mathrm{kg} /$ day and MTZ (10 mg/kg) and group 4B (10 mice), given AVA at a dose of $40 \mathrm{mg} / \mathrm{kg} /$ day and MTZ (10 mg/kg).

Group 5: 50 mice non-infected and treated with MTZ and AVA to act as drug control group, divided in to: $5 \mathrm{~A}$ : 10 mice received MTZ $10 \mathrm{mg} / \mathrm{kg}$. 5B: 10 mice received AVA $20 \mathrm{mg} / \mathrm{kg}$, 5C: 10 mice received AVA 40mg/kg. 5D: 10 mice received MTZ 10mg/kg and AVA 20 mg/kg, 5E: 10 mice received MTZ 10 mg/ $\mathrm{kg}$ and AVA $40 \mathrm{mg} / \mathrm{kg}$.

Group 6: 10 non-infected non-treated mice, maintained as control group.

\section{Statistical analysis}

It was performed using SPSS 16 (Chicago, Illinois, USA). The chi-square-test was used for association between 2 qualitatively expressed relationships. Significant levels were at $P$-value less than 0.05 .

\section{RESULTS}

\section{Parasitological assessment}

During direct examination of stools, Blastocystis was found mainly as cystic forms. While in culture, both vacuolar and granular forms were observed (Table 1).

\section{Reduction of Blastocystis shedding}

The therapeutic effects of the MTZ and AVA were apparently dose dependent (Table 1). The used regimens of AVA $(20 \mathrm{mg} /$ $\mathrm{kg}$ and $40 \mathrm{mg} / \mathrm{kg}$ ) proved effectiveness against Blastocystis in mice as evaluated by the higher percentage of reduction in Blas- 
Table 1. Blastocystis shedding per gram of feces $\times 10^{3}$ in different groups

\begin{tabular}{|c|c|c|c|c|}
\hline Group & $\begin{array}{l}\text { 5th day PI } \\
(\text { mean } \pm \text { SD) }\end{array}$ & $\begin{array}{l}\text { 10th day PI } \\
\text { (mean } \pm \text { SD) }\end{array}$ & $\begin{array}{l}\text { 15th day PI } \\
\text { (mean } \pm \text { SD) }\end{array}$ & $\begin{array}{l}\text { 20th day PI } \\
(\text { mean } \pm \text { SD) }\end{array}$ \\
\hline Group 1: (Infected non-treated control) & $42.6 \pm 8.3$ & $55.6 \pm 15.8$ & $85.4 \pm 12.6$ & $176.2 \pm 45.3$ \\
\hline Group 2: (Infected treated with MTZ 10 mg/kg) & $34.3 \pm 2.5^{\mathrm{a}}$ & $37.4 \pm 5.0^{\mathrm{a}}$ & $36.2 \pm 4.3^{\mathrm{a}}$ & $36.3 \pm 51.4^{\mathrm{a}}$ \\
\hline Group 3A: (Infected treated with AVA 20 mg/kg) & $29.2 \pm 3.8^{a, b}$ & $29.2 \pm 4.1^{\mathrm{a}, \mathrm{b}}$ & $20.2 \pm 14.5^{\mathrm{a}, \mathrm{b}}$ & $11.5 \pm 14.6^{a, b}$ \\
\hline Group 3B: (Infected treated with AVA 40 mg/kg) & $20.9 \pm 6.7^{a, b}$ & $17.1 \pm 7.2^{\mathrm{a}, \mathrm{b}}$ & $16.1 \pm 4.3^{\mathrm{a}, \mathrm{b}}$ & $3.6 \pm 11.7^{a, b}$ \\
\hline Group 4A: (Infected treated with AVA 20 mg/kg \& MTZ 10 mg/kg) & $14.8 \pm 5.3^{\mathrm{a}, \mathrm{b}}$ & $11.5 \pm 2.4^{\mathrm{a}, \mathrm{b}}$ & $8.5 \pm 3.3^{a, b}$ & $3.33 \pm 3.27^{a, b}$ \\
\hline Group 4B: (Infected treated with AVA 40 mg/kg \& MTZ 10 mg/kg) & $8.1 \pm 3.3^{a, b}$ & $6.4 \pm 2.8^{a, b}$ & $1.21 \pm 3.11^{a, b}$ & $1 \pm 2.2^{a, b}$ \\
\hline
\end{tabular}

Values are expressed as mean \pm SD.

aStatistically significant compared to infection control group $=P$-value $<0.05$.

bStatistically significant compared to MTZ treated group $=P$-value $<0.05$.

Table 2. Susceptibility of different Blastocystis genotypes to different drug formulations and doses

\begin{tabular}{lcccc}
\hline \multirow{2}{*}{ Group } & \multicolumn{3}{c}{ No. (\%) of mice harboring different genotypes } \\
\cline { 2 - 5 } & Genotype I & Genotype II & Genotype III & Genotype IV \\
\hline 1 (Infected non-treated) & $10(100)$ & $10(100)$ & $10(100)$ & $10(100)$ \\
2 (MTZ $10 \mathrm{mg} / \mathrm{kg})$ & $7(70)$ & $9(90)$ & $10(100)$ & $8(80)$ \\
3A (AVA $20 \mathrm{mg} / \mathrm{kg})$ & $7(70)$ & $10(100)$ & $9(90)$ & $8(80)$ \\
3B (AVA 40 mg/kg) & $3(30)$ & $6(60)$ & $7(70)$ & $4(40)$ \\
4A (MTZ $10 \mathrm{mg} / \mathrm{kg} \&$ AVA 20 mg/kg) & $2(20)$ & $3(30)$ & $4(40)$ & $3(30)$ \\
4B (MTZ 10 mg/kg \& AVA 40 mg/kg) & $0(0)$ & $0(0)$ & $1(10)$ & $2(20)$ \\
Total (n=50) & $29(58)$ & $38(76)$ & $41(82)$ & $35(70)$ \\
\hline
\end{tabular}

tocystis shedding ( $93.4 \%$ and $97.9 \%$ respectively) compared to MTZ alone (79.3\%). The highest percentage of reduction was recorded in groups treated with combinations of (AVA $20 \mathrm{mg} /$ $\mathrm{kg}$ and MTZ $10 \mathrm{mg} / \mathrm{kg})(98.1 \%)$ and (AVA $40 \mathrm{mg} / \mathrm{kg}$ and MTZ $10 \mathrm{mg} / \mathrm{kg}$ ) (99.4\%), both almost eradicated Blastocystis infection by 20 days PI (Table 1). There were significant differences in Blastocystis reduction between the control group and all treated groups $(P<0.05)$.

\section{Susceptibility of Blastocystis genotypes}

Genotyping of Blastocystis in human stool samples, culture and stool samples of infected (treated and non-treated) mice by PCR using STS primers revealed the presence of 4 genotypes; I, II, III, and IV in all examined samples. Genotype III was resistant to the effect of MTZ (10 mg/kg) while genotype II was resistant to AVA (20 mg/kg). On using AVA $40 \mathrm{mg} / \mathrm{kg}$, all genotypes were susceptible to that dose. Combination of MTZ $10 \mathrm{mg} / \mathrm{kg}$ with AVA $20 \mathrm{mg} / \mathrm{kg}$ induced a response in all genotypes. Combination of MTZ $10 \mathrm{mg} / \mathrm{kg}$ with AVA $40 \mathrm{mg} / \mathrm{kg}$ achieved complete eradication of genotypes I and II, while genotype III was detected only in 1 mouse and genotype IV was detected in 2 mice. In treated groups, genotype I represented the most susceptible genotype to all drug formulations as it was detected in 19 mice representing 38\% while genotype

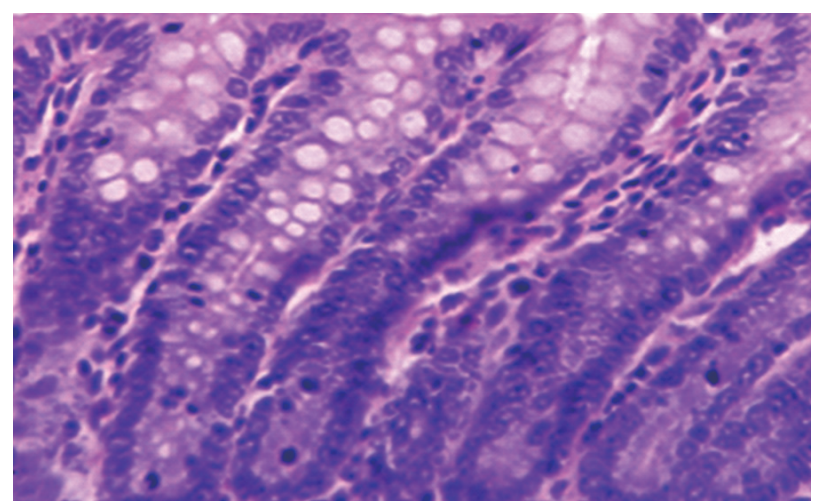

Fig. 1. Normal colon found in non-infected non-treated control group in the form of normal villous architecture and moderate number of goblet cells.

II was detected in $56 \%$ of mice, genotype III was present in $62 \%$ (most resistant genotype) and genotype IV was detected in $50 \%$ of mice (Table 2).

\section{Pathologic and TEM findings}

A normal control group showed healthy mucosal findings (Fig. 1). Pathologic findings revealed Blastocystis vacuolar forms at the mucosal epithelial surface without mucosal infiltration. This was accompanied by active intestinal infiltration of lymphocytes, eosinophils, and polymorphs with no ulcer- 


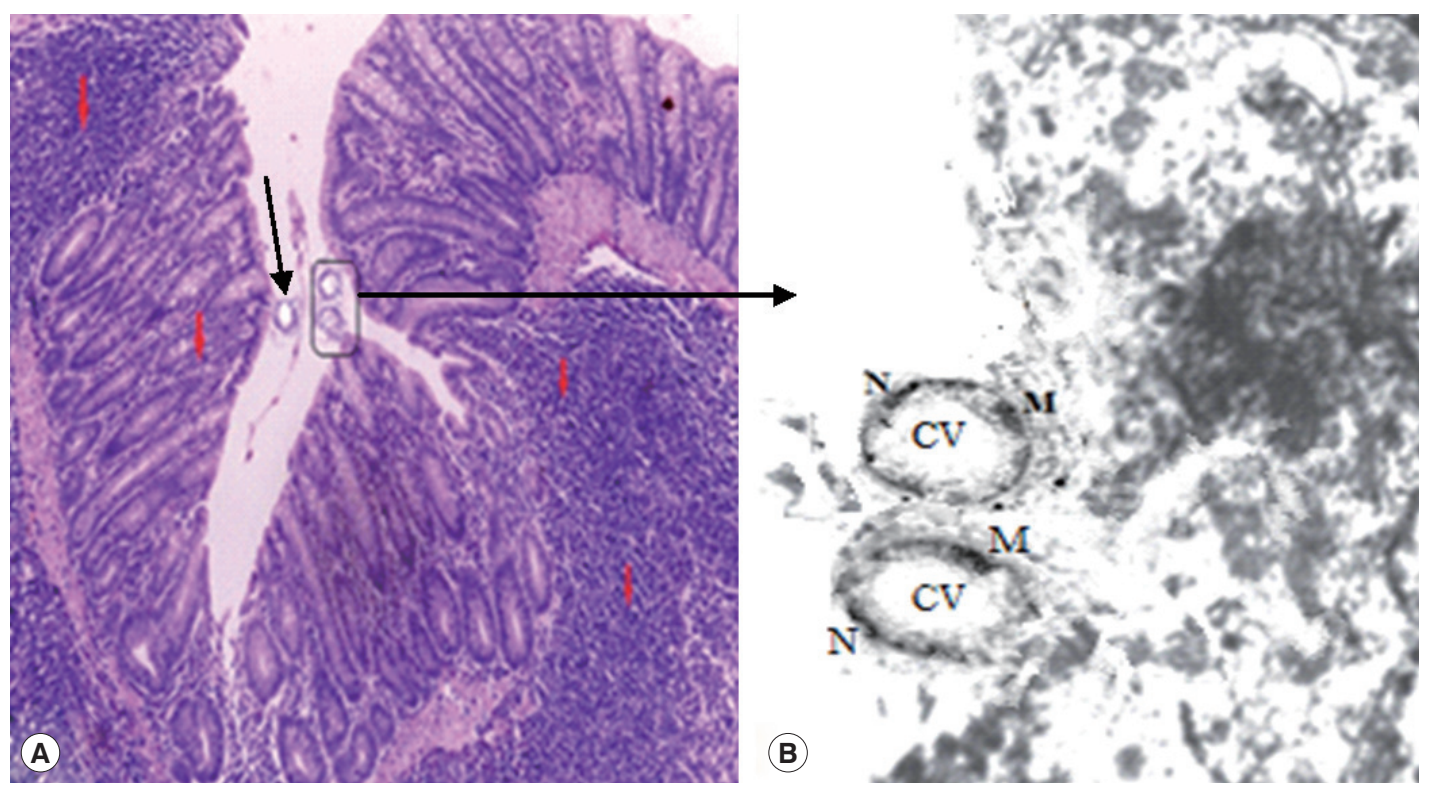

Fig. 2. (A) Active inflammatory changes in the form of increased inflammatory cells (red arrows) with shortened broad villi found in the colon of infected group treated with MTZ $10 \mathrm{mg} / \mathrm{kg}$ (21 days PI); black arrow indicates vacuolar form of Blastocystis with peripheral nuclei and central vacuole. (B) Boxed area of A was photographed using TEM to show Blastocystis vacuolar forms. M, mitochondrion; N, typical peripheral electron dense nuclei; CV, central vacuole $(\times 10,000)$.

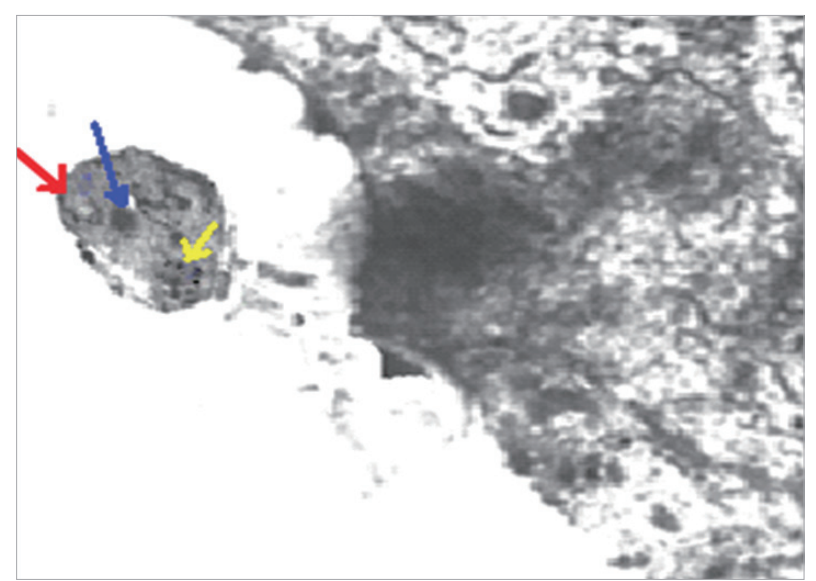

Fig. 3. TEM of Blastocystis from infected group treated with combined (AVA $40 \mathrm{mg} / \mathrm{kg}$ and MTZ $10 \mathrm{mg} / \mathrm{kg}$ ) (21 days PI) shows apoptotic changes in the form of electron dense granulation (absent central vacuole), swollen mitochondrion with tabulation of cristea (red arrow), swollen nucleus (blue arrow), chromatin scattered in clumbs (yellow arrow) and cytoplasmic streaks extend inwards from the irregular outer membrane $(\times 10,000)$.

ation or dysplasia but disturbed villus architecture (Fig. 2) with evident changes in the colon including hyperplasia of mucosa. Histopathological examination of the intestinal sections in group 3 treated with AVA (20 mg/ $/ \mathrm{kg}$ and $40 \mathrm{mg} / \mathrm{kg}$ ) revealed reduction in Blastocystis forms besides, an improvement of severity of bowel inflammatory lesions compared to the untreated groups in the form of partial healing of mucosal changes and villus architecture. Combinational therapy of AVA with MTZ (group 4) shows synergistic effects in the form of nearly absent Blastocystis forms, cessation of pathologic activity and marked improvement of inflammatory changes with enhancement of villus architecture compared to MTZ treated group which continues to have some activity of inflammatory changes and persistent disturbance of villus architecture.

The group 5 (non-infected drug control group) showed no pathological changes. Blastocystis vacuolar forms in mice treated with MTZ and AVA $40 \mathrm{mg} / \mathrm{kg}$ showed apoptotic changes as they exhibit electron dense granulation (absent central vacuole), swollen mitochondria with tabulation of cristea, swollen nuclei, chromatin scattered in clumbs and disarrangement of cytoplasm in the form of cytoplasmic streaks extend inwards from the irregular outer membrane (Fig. 3).

\section{DISCUSSION}

The antiparasitic activity of statins gained attention since 1995 through the potential inhibition of procyclic and epimastigote forms of trypanosomes by atorvastatin [27]. In addition, atorvastatin showed efficacy in treatment of schistosomiasis by inducing tegumental changes in worms with significant decline in worm burden and tissue egg loads [28]. Experi- 
mentally, atorvastatin proved potential effectiveness against tachyzoites of T. gondii [29-31]. Moreover, the drug proved antimalarial activity against both Plasmodium berghei and Plasmodium falciparum by mechanisms of action involving lactate dehydrogenase enzyme (PfLDH) and reverse cytoadherence to endothelial cells in vitro [32,33]. Statins have been demonstrated as excellent repurposing candidates for treatment of cryptosporidiosis in vitro [34]. Recently, anti-leishmanial effectiveness of atorvastatin and lovastatin was reported through inhibition of HMG-CoA reductase enzyme [35,36]. This antiparasitic activity of atorvastatin was supported by Mirza et al. [14] who described that statins could modulate or even cease the Blastocystis compromise of intestinal epithelium through inhibition of the isoprenylation process and induced activation of the ROCK pathway thus, blocking Blastocystis reorganization of the tight junction complex of intestinal epithelium and blocking the contravene of host epithelial permeability. Pradines et al. [37] proved the in vitro high vulnerability of $P$. falciparum to atorvastatin compared to the other 6 statins used in their study. Despite these promising results, the in vivo abilities of simvastatin and atorvastatin in Plasmodium berghei remained questionable [38,39]. These pleotropic activities of AVA, in addition to the scarce reports describing the interaction between statins and conventional anti-Blastocystis drugs, enthused our concern to the in vivo potentiality of using such drug for treatment of Blastocystis infection in comparison to MTZ as the standard anti-Blastocystis available therapy.

Studies hypothesized that AVA might act as an adjuvant therapy as AVA alone, at a dose of $20 \mathrm{mg} / \mathrm{kg}$ was not enough to rescue patients with cerebral malaria and was deficient to combat parasitemia in infected mice [40]. Thus, in the current study, the in vivo potential therapeutic effect of AVA was studied using 2 doses; $20 \mathrm{mg} / \mathrm{kg}$ which proved to have an inhibitory effect on growth of Plasmodium berghi in mice [25] and 40 $\mathrm{mg} / \mathrm{kg}$ which is the standard concentration commonly used and well tolerated in mice experiments [31]. What is more is that, we used the approach of combinational therapy of AVA and MTZ to explore the possible augmented therapeutic effects and highlighting the supplementary advantage of obstructing the process of drug-resistance. To our knowledge, the present study demonstrated for the first time the in vivo susceptibility of Blastocystis to AVA alone and in combination with MTZ.We found that AVA was effective against Blastocystis forms at $40 \mathrm{mg} / \mathrm{kg}$ which induced the highest reduction of Blastocystis shedding compared to AVA $(20 \mathrm{mg} / \mathrm{kg})$ and MTZ, a result that confirms the sensitivity of Blastocystis to that dose. It seems that this effect might be attributed mainly to Blastocystis damages occurred as a result of the possible influence of AVA on the biochemical pathways of the parasite. This hypothesis is acceptable in view of what is proved by Merza et al. [14] who described the dual effects of statins on Blastocystis and epithelial integrities through inhibition of HMG-COA reductase and cysteine proteases of Blastocystis besides abolishing enterocyte ROCK activities. The current study proved that genotype I was the most susceptible while genotype III proved to be the most resistant to the used drug formulations. On combinational therapy of AVA and MTZ, we found that these 2 drugs exhibited a strong synergy proved by the significant reduction of the recovered Blastocystis forms that were almost eradicated by 20 days PI. Moreover, our molecular study revealed that genotype III was resistant to MTZ when used alone but upon combination with AVA $(20 \mathrm{mg} / \mathrm{kg})$, all genotypes were susceptible to treatments and complete eradication of genotypes I and II was achieved upon using a higher dose of AVA ( $40 \mathrm{mg} / \mathrm{kg})$. This potentiated anti-Blastocystis activity was initiated earlier (5th day PI) when using AVA $40 \mathrm{mg} / \mathrm{kg}$ combined to MTZ. This may be due to the potential success of AVA at that higher dose to chiefly target the host cells as reported by Soliman and Ibrahim [28].

Consequently, combating the possible incidence of resistance of the parasite to MTZ that was previously reported by Haresh et al. [23]. Interestingly, this synergistic effect of both drugs may partially reconcile the argument regarding Blastocystis pathogenicity by effectively treating cases and evaluating whether the symptoms declared to be caused by the parasite improved or not. Blastocystis induced histopathologic consequences and the potential therapeutic effects of AVA discussed in this study showed significant improvement of the epithelial integrity in the experimental mice received AVA compared to MTZ. Furthermore, our results indicated that Blastocystis exposed to combinational therapy of AVA ( $40 \mathrm{mg} / \mathrm{kg}$ ) and MTZ showed apoptotic changes which confirm the dual effect of AVA in healing of the epithelial tissues and targeting Blastocystis which is in concur with Soliman and Ibrahim [28]. Thus, our results may support the previous observations of pathogenic potential of Blastocystis. Besides, indirectly, highlighting the role of Blastocystis in modulating the epithelial integrity through the significant results of AVA targeting blockade of Blastocystis effects in the used experimental model. Thus, offering a possible elucidation of intestinal inflammations associat- 
ing Blastocystis infections. In conclusion, the present study reports that AVA is a potential candidate for Blastocystis therapy. Mutually, AVA and MTZ regimens caused significant effects on Blastocystis infected mice with high synergy achieving complete Blastocystis eradication noticed in combined treatment. Genotype I represented the most susceptible genotype to drug formulations while genotype III was the most resistant.

Conclusively, results of our study might promote the use of AVA as a complement strategy to MTZ in advanced studies with particular insight to the use of statins as intestinal integrity protective factors.

\section{ACKNOWLEDGMENTS}

The experimental animal studies were maintained under convenient conditions at the animal house in the Faculty of Veterinary Medicine, Cairo University. The research was approved from the Scientific Research Ethical Committee, Faculty of Medicine, Cairo University, Egypt (Archiving no. 29/2017).

\section{CONFLICT OF INTEREST}

The authors have no conflicts of interest to disclose.

\section{REFERENCES}

1. Tan KS. New insights on classification, identification, and clinical relevance of Blastocystis spp. Clin Microbiol Rev 2008; 21: 639-665.

2. Alfellani MA, Stensvold CR, Vidal-Lapiedra A, Onuoha ES, Fagbenro-Beyioku AF, Clark CG. Variable geographic distribution of Blastocystis subtypes and its potential implications. Acta Trop 2013; 126: 11-18.

3. Stark D, van Hal S, Marriott D, Ellis J, Harkness J. Irritable bowel syndrome: A review on the role of intestinal protozoa and the importance of their detection and diagnosis. Int J Parasitol 2007; 37: 11-20.

4. Gallagher PG, Venglarcik JS 3rd. Blastocystis hominis enteritis. Pediatr Infect Dis 1985; 4: 556-557.

5. Tsang TK, Levin BS, Morse SR. Terminal ileitis associated with Blastocystis hominis infection. Am J Gastroenterol 1989; 84: 798799.

6. Mirza H, Teo JD, Upcroft J, Tan KS. A rapid, high-throughput viability assay for Blastocystis spp. reveals metronidazole resistance and extensive subtype dependent variations in drug susceptibilities. Antimicrob Agents Chemother 2011; 55: 637-648.

7. Stensvold CR, Smith HV, Nagel R, Olsen KE, Traub RJ. Eradication of Blastocystis carriage with antimicrobials: reality or delu- sion? J Clin Gastroenterol 2010; 44: 85-90.

8. Tan KS, Mirza H, Teo JD, Wu B, Macary PA. Current views on the clinical relevance of Blastocystis spp. Curr Infect Dis Rep 2010; 12: 28-35.

9. Johnson PJ. Metronidazole and drug resistance. Parasitology Today 1993; 9: 183-186.

10. Lemée V, Zaharia I, Nevez G, Rabodonirina M, Brasseur P, Ballet JJ, Favennec L. Metronidazole, albendazole susceptibility of 11 clinical isolates of Giardia duodenalis from France. J Antimicrob Chemother 2000; 46: 819-821.

11. Wang CY, Liu PY, Liao JK. Pleiotropic effects of statin therapy: molecular mechanisms and clinical results. Trends Mol Med 2008; 14: 37-44.

12. Zhou Q, Liao JK. Statins and cardiovascular diseases: from cholesterol lowering to pleiotropy. Curr Pharm Des 2009; 15: 467478.

13. Rodríguez C, Alcudia JF, Martínez-González J, Guadall A, Raposo B, Sánchez-Gómez S, Badimon L. Statins normalize vascular lysyl oxidase down regulation induced by proatherogenic risk factors. Cardiovasc Res 2009; 83: 595-603.

14. Mirza H, Wu Z, Teo JD, Tan KS. Statin pleiotropy prevents rho kinase-mediated intestinal epithelial barrier compromise induced by Blastocystis cysteine proteases. Cell Microbiol 2012; 14: 1474-1484.

15. Dagci H, Ustun S, Taner MS, Ersoz G, Karacasu F, Budak S. Protozoon infections and intestinal permeability. Acta Trop 2002; 81: $1-5$.

16. Puthia MK, Sio SW Lu J, Tan KS. Blastocystis ratti induces contactindependent apoptosis, F-actin rearrangement, and barrier function disruption in IEC-6 cells. Infect Immun 2006; 74: 41144123.

17. Jones WR. The experimental infection of rats with Entamoeba histolytica with a method for evaluating the anti-amoebic properties of new compounds. Ann Trop Med Parasitol 1946; 40: 130140.

18. Eida OM, Hussein EM, Eida AM, El-Moamly AA, Salem AM. Evaluation of the nitric oxide activity against B.hominis in vitro and in vivo. J Egypt Soc Parasitol 2008; 38: 521-536.

19. Parkar U, Traub RJ, Kumar S, Mungthin M, Vitali S, Leelayoova S, Morris K, Thompson RC. Direct characterization of Blastocystis from feces by PCR and evidence of zoonotic potential. Parasitology 2007; 134: 359-367.

20. Yang LQ, Singh M, Yap EH, Ng GC, Xu HX, Sim KY. In vitro response of Blastocystis hominis against traditional Chinese medicine. J Ethnopharmacol 1996; 55: 35-42.

21. Shlim DR, Hoge CW, Rajah R, Rabold JG, Echeverria P. Is Blastocystis hominis a cause of diarrhea in travelers? A prospective controlled study in Nepal. Clin Infect Dis 1995; 21: 97-101.

22. Yoshikawa H, Abe N, Wu Z. PCR-based identification of zoonotic isolates of Blastocystis from mammals and birds. Microbiology 2004; 150: 1147-1151.

23. Haresh K, Suresh K, Khairul Anuar A, Saminathan S. Isolate resistance of Blastocystis hominis to metronidazole. Trop Med Int 
Health 1999; 4: 244-277.

24. Becker S, Hoffman P, Houpt ER. Efficacy of antiamebic drugs in a mouse model. Am J Trop Med Hyg 2011; 84: 581-586.

25. Penna-Coutinho J, Cortopassi WA, Oliveira AA, França TC, Krettli AU. Antimalarial activity of potential inhibitors of Plasmodium falciparum lactate dehydrogenase enzyme selected by docking studies. PLoS One 2011; 6: e21237.

26. Moe KT, Singh M, Howe J, Ho LC, Tan SW, Chen XQ, Ng GC, Yap EH. Experimental Blastocystis hominis infection in laboratory mice. Parasitol Res 1997; 83: 319-325.

27. Coppens I, Bastin P, Levade T, Courtoy PJ. Activity, pharmacological inhibition and biological regulation of 3-hydroxy3-methylglutaryl coenzyme A reductase in Trypanosoma brucei. Mol Biochem Parasitol 1995; 69: 29-40.

28. Soliman MF, Ibrahim MM. Antischistosomal action of atorvastatin alone and concurrently with medroxyprogesterone acetate on Schistosoma haematobium harboured in hamster: surface ultrastructure and parasitological study. Acta Trop 2005; 93: 1-9.

29. Cortez E, Stumbo AC, Oliveira M, Barbosa HS, Carvalho L. Statins inhibit Toxoplasma gondii multiplication in macrophages in vitro. Int J Antimicrob Agents 2009; 33: 185-186.

30. Nishikawa Y, Quittnat F, Stedman TT, Voelker DR, Choi JY, Zahn M, Yang M, Pypaert M, Joiner KA, Coppens I. Host cell lipids control cholesteryl ester synthesis and storage in intracellular Toxoplasma. Cell Microbiol 2005; 7: 849-867.

31. Li ZH, Ramakrishnan S, Striepen B, Moren SN. Toxoplasma gondii relies on Both Host and Parasite Isoprenoids and Can Be Rendered Sensitive to Atorvastatin. PLoS Pathog 2013; 9: e1003665.

32. Parquet V, Briolant S, Torrentino-Madamet M, Henry M, Almeras L, Amalvict R, Baret E, Fusaï T, Rogier C, Pradines B. Atorvastatin is a promising partner for antimalarial drugs in treatment of Plasmodium falciparum malaria. Antimicrob Agents Chemother 2009; 53: 2248-2252.
33. Taoufiq Z, Gay F, Balvanyos J, Ciceron L, Tefit M, Lechat P, Mazier D. Rho kinase inhibition in severe malaria: thwarting parasite induced collateral damage to endothelia. J Infect Dis 2008; 197: 1062-1073.

34. Bessoff K, Sateriale A, Lee KK, Huston CD. Drug repurposing screen reveals FDA-approved inhibitors of human HMG-CoA reductase and isoprenoid synthesis that block $C$. parrum growth. Antimicrob Agents Chemother 2013; 57: 1804-1814.

35. Dinesh N, Pallerla DS, Kaur PK, Kishore Babu N, Singh S. Exploring Leishmania donovani 3-hydroxy-3-methylglutaryl coenzyme A reductase (HMGR) as a potential drug target by biochemical, biophysical and inhibition studies. Microb Pathog 2014; 66: 14-23.

36. Kumar GA, Roy S, Jafurulla M, Mandal C, Chattopadhyay A. Statin-induced chronic cholesterol depletion inhibits Leishmania donovani infection: Relevance of optimum host membrane cholesterol. Biochim Biophys Acta 2016; 1858: 2088-2096.

37. Pradines B, Torrentino-Madamet M, Fontaine A, Henry M, Baret E, Mosnier J, Briolant S, Fusai T, Rogier C. Atorvastatin is 10-fold more active in vitro than other statins against Plasmodium falciparum. Antimicrob Agents Chemother 2007; 51: 2654-2655.

38. Bienvenu AL, Picot S. Statins alone are ineffective in cerebral malaria but potentiate artesunate. Antimicrob Agents Chemother 2008; 52: 4203-4204.

39. Kobbe R, Schreiber N, May J, Jacobs T. Simvastatin treatment shows no effect on the incidence of cerebral malaria or parasitemia during experimental malaria. Antimicrob Agents Chemother 2008; 52: 1583-1584.

40. Savini H, Souraud JB, Briolant S, Baret E, Amalvict R, Rogier C, Pradines B. Atorvastatin as a potential antimalarial drug: in vitro synergy in combinational therapy with dihydroartemisinin. Antimicrob Agents Chemother 2010; 54: 966-967. 